\title{
Investigation of the Effects of Repeated Frying on the Quality of Vegetable Oil
}

\author{
Maduelosi Ngozi Jane*, Cookey Grace \\ Department of Chemistry, Rivers State University, Port Harcourt, Nigeria \\ Email address: \\ janemaduelosi@yahoo.com (M. N. Jane) \\ ${ }^{*}$ Corresponding author
}

To cite this article:

Maduelosi Ngozi Jane, Cookey Grace. Investigation of the Effects of Repeated Frying on the Quality of Vegetable Oil. American Journal of Applied Chemistry. Vol. 8, No. 4, 2020, pp. 117-120. doi: 10.11648/j.ajac.20200804.13

Received: September 22, 2019; Accepted: October 18, 2019; Published: August 31, 2020

\begin{abstract}
Refined vegetable oil (Kings brand), was purchased from Mile 3 Market, Port Harcourt, Nigeria and was repetitively used in frying Akara balls for a period of 24 hours, at intervals of four hours per day, for six days. The effect of heat and repetitive use for frying on quality of the oil was monitored by the measurement of the physico-chemial parameters of the oil after each frying period. The density, $\%$ free fatty acid, viscosity, peroxide value and iodine value of the fresh and used oil were determined to investigate the level of deterioration. The results obtained show that the values of the parameters increased with frying time except that of iodine value which decreased with frying time. The free fatty acid value increased from $0.06-.56 \%$, density increased from $0.900-0.910 \mathrm{~g} / \mathrm{ml}$, viscosity increased from $23.33-28.31 \mathrm{~mm}^{2} / \mathrm{s}$, peroxide value increased from $1.988-4.879 \mathrm{meqO}_{2} / \mathrm{Kg}$ and iodine value decreased from $43.35-29.83$ wijis. These changes are attributed to the destruction of the chemical structures of the triacylglycerols and formation of new products in the oil by heat. The increase in the density and viscosity shows that as frying progressed, denser and higher molecular weight compounds are formed thereby rendering the used oil more viscous. The increase in peroxide values may be due the formation of peroxides as the primary products of oxidation. The formation of peroxides leads to loss of unsaturation in the oil which is seen as a reduction in iodine value of the oil. The sweet aroma of the oil was also lost as frying progressed as a result of de-esterification of the oil and formation of secondary oxidation products that impart off-flavours to the oil. The findings show that repeated use of vegetable oil for frying leads to deterioration/degration of the oil.
\end{abstract}

Keywords: Oxidation, Physico-Chemical Parameters, Vegetable Oil, Frying, Akara Balls, Heat

\section{Introduction}

Vegetable oils are composed of triglycerides which are extracted from seeds or nuts of vegetables. Some are used in food preparation while others are used for industrial purposes. The nutritional value of vegetable oils is due to their vitamin, some phytochemicals and essential fatty acid contents. For example, virgin olive oils are valuable due their unique contents. Olive oil, in addition to the triacylglycerols, contain beta-carotene and some phenolics that enable the oil to have antioxidant potentials. These components are believed to protect humans against cardiovascular diseases [1]. The quality of given oil is indicated by some physico-chemical parameters such as the iodine value, peroxide value, free fatty acid value, refractive index, density, viscosity among others. The edibility and specific applications of a vegetable oil is indicated by these parameters. The exposure of oils to light, heat or air leads to the alteration of these parameters and an attendant loss in quality due to formation of offflavours, colour defects as well as loss in nutritional quality [2]. This is because the essential fatty acids and vitamin present in the oil are oxidizable. Some of these fatty acids include:

Lauric - $\mathrm{CH}_{3}\left(\mathrm{CH}_{2}\right)_{10} \mathrm{CO}_{2} \mathrm{H}$

Myristic - $\mathrm{CH}_{3}\left(\mathrm{CH}_{2}\right)_{12} \mathrm{CO}_{2} \mathrm{H}$

Palmitic - $\mathrm{CH}_{3}\left(\mathrm{CH}_{2}\right)_{14} \mathrm{CO}_{2} \mathrm{H}$

Stearic - $\mathrm{CH}_{3}\left(\mathrm{CH}_{2}\right)_{16} \mathrm{CO}_{2} \mathrm{H}$

Oleic - $\mathrm{CH}_{3}\left(\mathrm{CH}_{2}\right)_{7} \mathrm{CH}=\mathrm{CH}\left(\mathrm{CH}_{2}\right)_{7} \mathrm{CO}_{2} \mathrm{H}$

Linoleic - $\mathrm{CH}_{3}\left(\mathrm{CH}_{2}\right)_{4} \mathrm{CH}=\mathrm{CHCH}_{2} \mathrm{CH}=\mathrm{CH}\left(\mathrm{CH}_{2}\right)_{7} \mathrm{CO}_{2} \mathrm{H}$ and

Linolenic - $\mathrm{CH}_{3} \mathrm{CH}_{2} \mathrm{CH}=\mathrm{CHCH}_{2} \mathrm{CH}=\mathrm{CHCH}_{2} \quad \mathrm{CH}=\mathrm{CH}$ $\left(\mathrm{CH}_{2}\right)_{7} \mathrm{CO}_{2} \mathrm{H}$ with sigma and pi bond linkages. 
Frying is one of the most common methods of food preparation as it renders the food more durable and palatable. Some common foods prepared by frying include: fish, meat, Akara, plantain, yam, potato, confectionaries, etc. Consumption of oxidized products from oils used repeatedly in frying processes generates some potential health hazards $[3,4]$. Unfortunately, it has been found that vegetable cooking oils are used in most homes 3-6 times before being discarded as waste so as to cut down on cost.

The repeated use of vegetable oils for frying causes several oxidative and thermal reactions that result in changes in physico-chemical, nutritional and sensory properties of vegetable oils [5]. The degree of changes in the physical and chemical properties of the oil dictates the quality of the oil for human consumption. Some earlier researchers reported that during frying, changes such as hydrolysis, oxidation and polymerization processes take place in the oil and these affect the composition, flavor and stability of vegetable oils $[4,6]$. Degraded products of vegetable oils include: free fatty acids, hydroperoxides and polymerized triacylglycerols [7]. The accumulation of deterioration products in the course continuous heating at high temperature leads to organoleptic failures and formation of toxic compounds in the oil [8]. The presence of excess polar compounds in repeatedly used frying oil has been associated with increased risk of developing hypertension and low density lipoprotein level [9]. In 1991, investigation of the changes in deep-fat frying was carried out and the researchers found out that the presence of air and water accelerated the rate of deterioration of the frying oil and increased the number of polar molecules as confirmed by viscosity and density data of the oil studied [10]. Some other researchers monitored the oxidative changes in five vegetable oils (sunflower, grape seed, soya bean, corn and olive oils) caused by frying temperature [11]. The oils were heated continuously at $180+5^{\circ} \mathrm{C}$ in an oven. Samples were withdrawn at regular time intervals for analysis to determine unchanged triacylglycerols, total polar components, peroxide value and conjugated dienes and trienes. The results show changes in the C18:2 to C16:0 ratios, increase in total polar components and conjugated dienes and trienes, indicating deterioration in the oils. Reports on regeneration of thermally polymerized frying oils with adsorbents presented by some researchers show that atmospheric oxygen reacts instantly with lipid and other organic compounds of the oil to cause structural degradation in the oil, which leads to loss of quality of food and possibly cause harm to human health [12].

This study was carried out to determine the effect of heat and repeated frying on the quality of vegetable oil with time so that the use of oil that has gone bad can be discouraged in other to prevent possible health consequences. The vegetable oil used for the study is the "'kings brand" vegetable oil with smoke point value of $270^{\circ} \mathrm{C}$, justifying the oil's suitability for frying purposes.

\section{Materials and Methods}

Ten (10) liters of Kings brand of vegetable oil and iron bean seeds were obtained from local suppliers at Mile 3 Market in Nkpolu-Oroworukwo, Port-Harcourt, Rivers state. The bean seeds were washed to remove the back and ground to thick paste. The paste was made into balls (Akara) and fried in the oil for a period of four hours daily, for six days in the same oil. At the end of each frying session, $100 \mathrm{mls}$ portions of the oil was taken for analysis for changes in density, viscosity, $\%$ free fatty acid, peroxide value and iodine value in other to assess the changes in physicochemical parameters and degree of deterioration. The parameters were analyzed according to the American Oil Chemists Society (AOCS, 1986) official methods [18].

Statistical Analysis

All the analyses were carried out in triplicate. The obtained data were subjected to analysis of variance (ANOVA). The difference between means were evaluated using Turkey's multiple comparison test and significance accepted at $\mathrm{p} \leq 0.05$ level. The statistical package in Minitab 16 computer programme was used.

\section{Results}

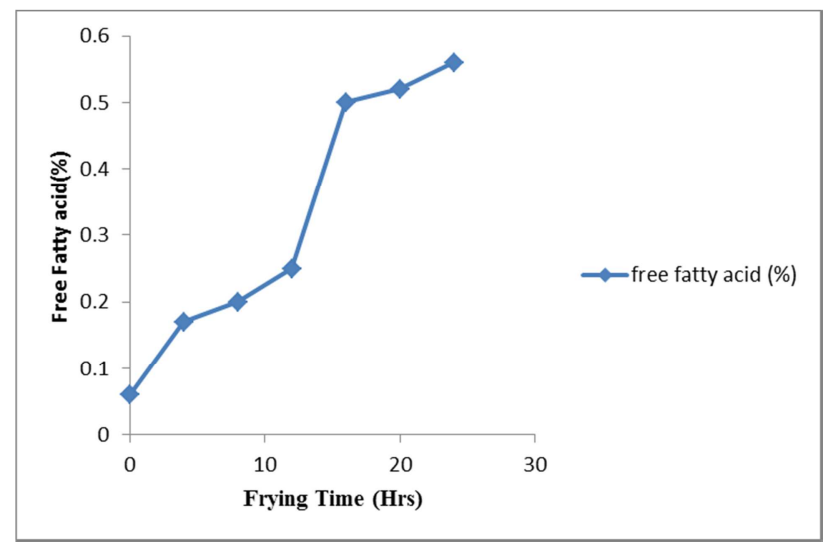

Figure 1. Plots of \% Free fatty acid versus Frying Time.

Table 1. Physico-Chemical Properties of the Vegetable Oil Before and After Frying.

\begin{tabular}{|c|c|c|c|c|c|}
\hline Frying time (Hours) & Free fatty acid (\%) & Density (glml) & Viscosity $\left(\mathrm{mm}^{2} / \mathrm{s}\right)$ & Peroxide value (meq02/kg) & Iodine value (wijis) \\
\hline 0 (control) & $0.06^{\mathrm{e}} \pm 0.011$ & $0.900^{c} \pm 0.001$ & $23.33^{\mathrm{g}} \pm 0.021$ & $1.988^{\mathrm{f}} \pm 0.016$ & $43.35^{\mathrm{a}} \pm 0.031$ \\
\hline 4 & $0.17^{\mathrm{d}} \pm 0.012$ & $0.901^{\mathrm{bc}} \pm 0.001$ & $25.70^{\mathrm{f}} \pm 0.020$ & $1.912^{\mathrm{f}} \pm 0.018$ & $42.70^{\mathrm{b}} \pm 0.030$ \\
\hline 8 & $0.20^{\mathrm{d}} \pm 0.012$ & $0.902^{\mathrm{bc}} \pm 0.002$ & $27.36^{\mathrm{e}} \pm 0.022$ & $2.993^{\mathrm{e}} \pm 0.017$ & $41.72^{c} \pm 0.032$ \\
\hline 16 & $0.50^{\mathrm{b}} \pm 0.020$ & $0.904^{\mathrm{b}} \pm 0.001$ & $27.91^{c} \pm 0.016$ & $3.827^{\mathrm{c}} \pm 0.015$ & $34.98^{\mathrm{e}} \pm 0.025$ \\
\hline 20 & $0.52^{\mathrm{ab}} \pm 0.021$ & $0.908^{\mathrm{a}} \pm 0.001$ & $28.05^{\mathrm{b}} \pm 0.011$ & $4.406^{\mathrm{b}} \pm 0.011$ & $33.72^{\mathrm{f}} \pm 0.035$ \\
\hline 24 & $0.56^{\mathrm{a}} \pm 0.011$ & $0.910^{\mathrm{a}} \pm 0.001$ & $28.31^{\mathrm{a}} \pm 0.030$ & $4.879^{\mathrm{a}} \pm 0.013$ & $29.83^{\mathrm{g}} \pm 0.030$ \\
\hline
\end{tabular}

Values are means \pm standard deviation of triplicate samples. Mean values bearing different superscripts in the same column differ significantly ( $\mathrm{p} 0.05$ ). 


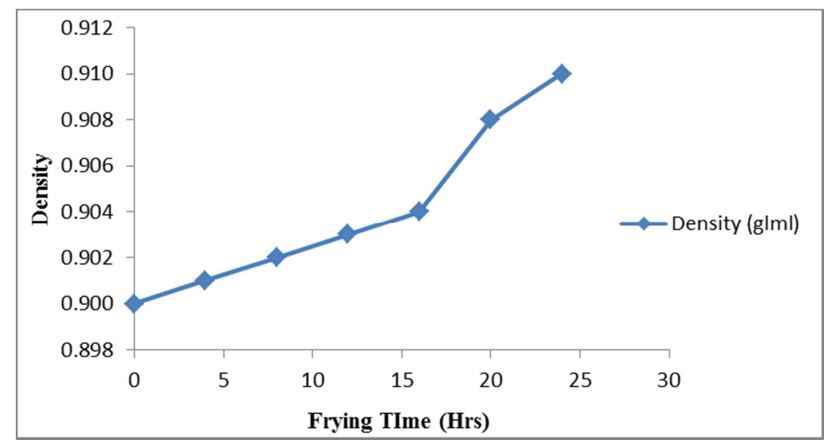

Figure 2. Plots of Densities versus Frying Time.

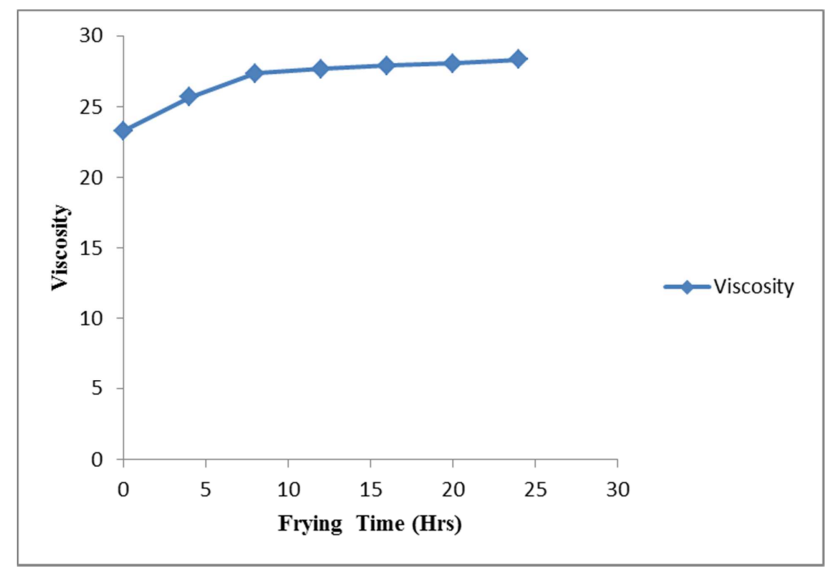

Figure 3. Plots of Viscosities versus Frying Time.

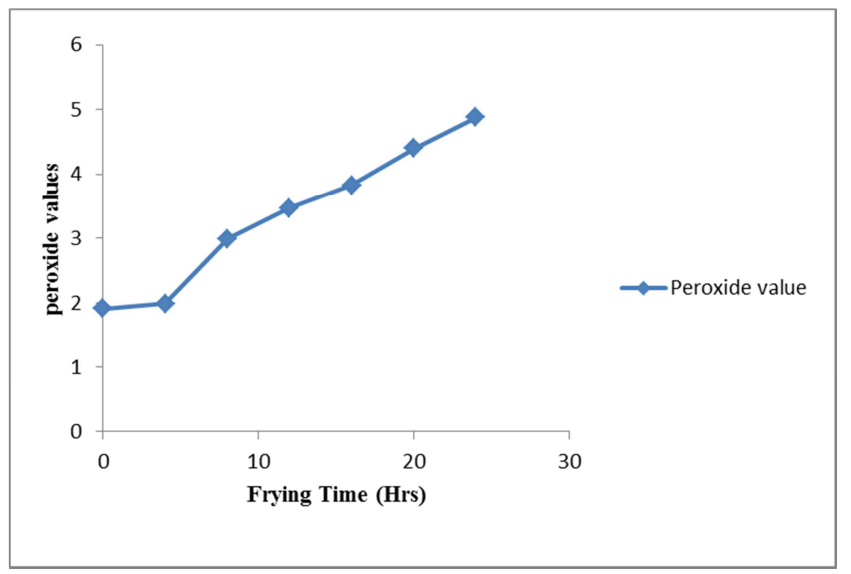

Figure 4. Plots of Peroxide values versus Frying Time.

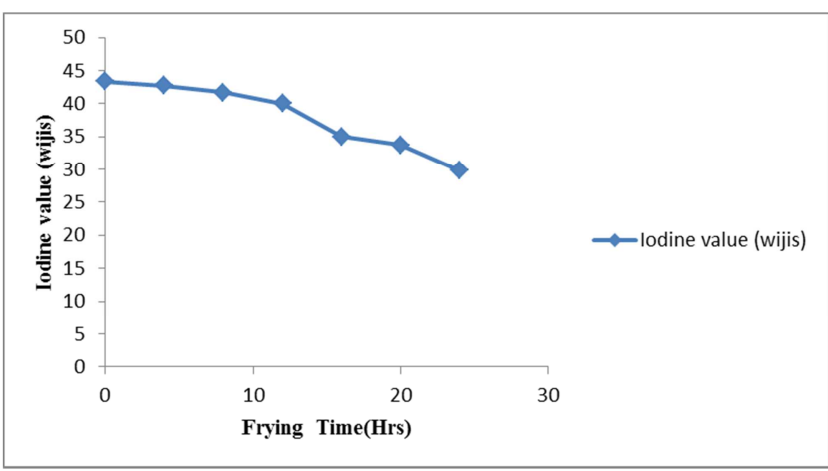

Figure 5. Plots of Iodine values versus Frying Time.

\section{Discussions}

Percentage (\%) Free fatty acids: The results of the $\%$ free fatty acid presented in Table 1and Figure 1 show an increase from $0.06 \%$ for the control to $0.56 \%$ for the heated oil. This increase in $\%$ free fatty acid with frying time may be as a result of the breakdown of the primary oxidation product (hydroperoxides) to free fatty acids as frying progressed. The increase is also attributed to hydrolysis of the oil, which may have resulted from the moisture from the Akara balls. Similar observations have been made [13]. Increase in \% free fatty acids, which are unesterified fatty acids in the oil leads to loss of flavor/rancidity of the oil as reported by earlier researchers [2, 14].

Iodine value: The iodine values of the oil samples decreased from 43.35 wijs (for the control) to 29.83 wijs for the heated oil. This decrease is attributed to loss of unsaturation with frying time. When oils are exposed to heat or heated at elevated temperatures, the double bond in the acyl chains in the component triacylglycerols of the oil are broken as a result of oxidation and polymerization reactions. Similar observations have made $[15,16]$.

Peroxide value: The results from the analysis show that the peroxide values of the oil samples increased with increase in frying time from $1.54 \mathrm{meqO}_{2} / \mathrm{kg}$ oil (for the control) to 5.99 $\mathrm{meqO}_{2} / \mathrm{kg}$ oil for the heated sample. This is attributed to the formation of primary oxidation product (hydroperoxides) as heat is applied. The hydroperoxides formed results in the formation of off-flavour compounds in the oil. Similar reports have been made [2, 17].

Viscosity and Density values: The density values showed a steady increase with frying time from 0.900 to $0.910 \mathrm{~g} / \mathrm{ml}$. The viscosity values also increased from $23.3 \mathrm{~mm}^{2} / \mathrm{s}$ to $28.31 \mathrm{~mm}^{2} / \mathrm{s}$. The reasons for the increase may be as a result of air and water from the Akara balls which results in formation of polar/ higher molecular weight compounds. The continuous frying with the oil gave rise to formation of denser and viscous products. This observation is consistent with earlier results given $[10,11]$.

\section{Conclusion}

The results of this study show that repeated use of vegetable oil for frying reduces the quality of the oil via changes in the composition of the oil. The values of all the parameters measured increased with frying time except the iodine values that decreased. This shows deterioration of the oil. It is the opinion of the authors that the repeated use of vegetable oil should be discouraged and further research should also be carried out for longer heating periods.

\section{Acknowledgements}

We wish to acknowledge the contributions of Onuoha Glory and Mr. Justice Okwechime in this study. 


\section{References}

[1] Covas, M. I. \& Gaddi, A. V. Relationship of olive oil polyphenols and oxidation biomarkers. Journal of Nutrition. 2011, 141 (12) 2256.

[2] Fekarurhobo, G. K., Obomanu, F. G., \& Maduelosi, N. J. Effect of Short Term Exposure to Sunlight on the Quality of some Edible oils. Research Journal of Applied Sciences. 2009. 4 (5): 152-156.

[3] Gotoh, N., Ai-Iwasawa, H., Watanabe, R., O. \& Wada, S. Oxidation of Fats and Oils in instant noodles stored under various conditions. Journal of Food Lipids. 2007. 14, 350-365.

[4] Maduelosi, N. J., Obediah, G. A. \& Ogbonna, O. D. Effects of Vegetable Oil Reused for Frying on the Liver of Albino Rats. Science Journal of Chemistry. 2019.7 (1). 11-14.

[5] Cheman, Y. B. \& Jasvir, I. Effect of Rosemary and Sage extracts on frying performance of refined, bleached and deodorized (RBD) Palm Olein during deep frying. Food Chemistry. 2000, 69, 301-307.

[6] Gloria, H., \& Aguilera, J. M. Assessment of the quality of heated oils by differential scanning calorimetry. Journal of Agriculture and Food Chemistry. 1998. 46, 1363-1368.

[7] Choe, E. \& Min, D. B. Chemistry of Deep-frying oils. 2007. Journal of Food Sciences. 72: 77-86.

[8] Romero, A., Bastida, S. \& Sanchez-Muniz, F. J. Cyclic fatty acid monomer formation in domestic frying of frozen foods in sunflower oil with high oleic acid. Food and Chemical Toxicology. 2006. 44: 1674-1681.

[9] Garrido-Polonio, C., Garcia-Linares, M. C., Garcia-Arias, M. T., Lopes-Varela, S., Garcia-Katragadda, H. R., Fullana, A., Sidhu, S \& Carbowell-Barrachina, A. A. Emissions of volatile aldehydes from heated cooking oils. Food Chemistry. 2009. $120,59-65$.

[10] Cleark, W. L. \& Serbia G. W. Safety aspects of frying fats and oil; Food Technology. 1991. 45 (2) 84-89.

[11] Marinova, E. M., Seizova, K. A., Totseva, I. R., Panayotova, S. S., Marekor. I. N. \& Momchilova, S. M. Oxidative changes in some vegetable oils during heating at frying temperature. Bulgarian Chemical Communications. 2012. 44 (1) 57-63.

[12] Bhattacharya, A. B., Sajilata, M. G., Tiwari, S. R \& Singhal, R Regeneration of thermally polymerized frying oils with adsorbent. Food Chemistry. 2008. (110), 562-570.

[13] Al-fatlawi, A. M. L., \& Abbas, N. M. Investigating Peroxide and Acid value in used Edible vegetable oil. The Iraqi Journal of Agricultural Science. 2010. 41 (4): 13-132.

[14] Maduelosi N. J., \& Worlu G. E. Effect of Photo-Oxidized Groundnut oil (Arachis hypogea) on the Liver Enzymes of Albino Rats. International Journal of Advanced Research in Chemical Science. 2015. 2 (11) 5-7.

[15] Reblova, Z. Rudrrova J. Trojahova L. \& Pokorry. Unsaturated fatty acids as compared to saturated acid. Food lipids. 1999. 6.13 .

[16] Tynek, M., Hazuka, Z., Pawlowiz P. \& Oudek, M. Loss of Unsaturation in the Composition of the Vegetable oil as Frying Progressed. Journal of Food Lipids. 2001. 8. 251.

[17] Daya, G., Padmini, S. \& Wind, R. Measurement of peroxides in oils and fats. Cons. Stand \& home Eco. 2004. 24: 223.

[18] American Oil Chemists Society (AOCS). Sampling and Analysis of Commercial Fats and Oils. Washington D. C, 1986. 